\title{
Reinterpretasi Jihad dalam Pendidikan di Era Digital
}

\author{
Tian Wahyudi \\ Universitas Islam Indonesia \\ tianwahyudi@uii.ac.id
}

\begin{abstract}
This article examines the urgency of jihad in education and the role of the ummah in actualizing it in the digital era. The method used in this research is literature study, namely by collecting, selecting and sorting library materials relevant to the topics discussed, then analyzing and interpreting it. Jihad in Education is earnest effort for mukmin with all his abilities in order to provide a quality education intended for Muslims in ways that are in accordance with the guidance of the Shari'a in order to gain the pleasure of Allah. Jihad in education demands a collaborative role for all elements of the ummah, both their role as Muslim individuals and their role in the Muslim community. Jihad in education is very important to be actualized according to the role and abilities Muslim. As for the forms of jihad in education, namely: 1) jihad against lust as a basis for carrying out other jihad activities;2) Jihad parents in educating their children;3) jihad teachers in educating generations of ummah;4) jihad students in studying; 5) jihad assets used for the benefit of Islamic education;6) jihad through virtual media, namely by presenting educational and Islamic content in various digital media in various forms.
\end{abstract}

Keyword: Digital Era, Education, Jihad

\begin{abstract}
Abstrak
Artikel ini mengkaji bagaimana urgensi jihad dalam bidang pendidikan dan peran umat dalam mengaktualisasikannya di era digital. Metode yang digunakan dalam penelitian ini yaitu studi literatur, yakni dengan mengumpulkan, memilih dan memilah bahan pustaka yang relevan dengan topik yang dibahas, kemudian dilakukan analisis dan interpretasi. Jihad pendidikan yaitu upaya serius dan sungguh-sungguh seorang mukmin dengan segala kemampuan yang dimilikinya demi terselenggaranya pendidikan yang berkualitas yang diperuntukan bagi umat Islam dengan cara-cara yang sesuai dengan tuntunan syariat demi menggapai ridha Allah SWT. Jihad pendidikan menuntut peran kolaboratif semua elemen umat, baik perannya sebagai individu muslim, maupun perannya dalam komunitas masyarakat muslim. Jihad pendidikan sangat penting untuk diaktualisasikan sesuai peran dan kemampuan seorang muslim. Adapun yang menunjukan bentuk-bentuk jihad pendidikan, yaitu: 1) jihad melawan hawa nafsu sebagai dasar dalam menjalankan aktivitas jihad lainnya; 2) Jihad orang tua dalam mendidik anak-anaknya; 3 ) jihad guru dalam mendidik generasi umat; 4) jihad peserta didik dalam menuntut ilmu; 5) jihad harta yang digunakan untuk kepentingan pendidikan Islam; 6) jihad melalui media virtual, yaitu dengan menghadirkan konten-konten edukatif dan Islami di berbagai media digital dalam berbagai bentuk.
\end{abstract}

Kata Kunci: Jihad, Pendidikan, Era Digital

\section{Pendahuluan}

Membangun pendidikan Islam hakikatnya adalah membangun kualitas umat. Hal ini karena pendidikan merupakan sarana utama pembentukan sumber daya manusia. 
Kualitas manusia banyak ditentukan oleh seberapa baik kualitas pendidikannya. Oleh karenanya, pembangunan pendidikan memerlukan perhatian dan upaya serius dari banyak elemen umat.

Disamping hal di atas, permasalahan pendidikan juga semakin hari semakin kompleks dan beragam. Hadirnya teknologi digital dengan beragam inovasinya tidak hanya memberi kemudahan bagi manusia, namun pada saat bersamaan menghadirkan beragam problematika baru bagi kehidupan generasi muda. Berbagai kasus mental dan moral yang dapat disaksikan melalui pemberitaan di berbagai media, seperti pornografi, ${ }^{1}$ pergaulan bebas-seks pra nikah, ${ }^{2}$ perudungan maya, ${ }^{3}$ pelecehan siswa terhadap guru, ${ }^{4}$ vandalisme, ${ }^{5}$ kecanduan game online sehingga menurunkan prestasi belajar dan berbagai kegiatan positif lainnya, ${ }^{6}$ kurangnya kemampuan sosialisasi dengan teman sejawat dalam dunia nyata, ${ }^{7}$ dan lain sebagainya merupakan tantangan nyata yang harus dihadapi dunia pendidikan saat ini.

Dalam menghadapi permasalahan pendidikan di atas seyogyanya umat Islam kembali kepada agamanya yang memiliki ajaran-ajaran mulia, yang dengannya mampu memandu dan mengantarkan manusia kepada keberhasilan dalam membangun kehidupannya. Salah satu di antara ajaran mulia yang dapat diterapkan dalam upaya membangun pendidikan yang berkualitas adalah ajaran tentang jihad. Hal ini karena dalam makna jihad terkandung spirit dan semangat teologis yang bertujuan menggapai keridaan Allah SWT. Oleh karena itu, dalam konteks inilah penting merevitalisasi jihad dalam arti yang luas bagi setiap individu muslim.

Makna jihad itu sendiri sebenarnya bila ditelusuri dari berbagai pendapat para ulama maupun cendikiawan muslim, ditemukan pendapat yang beragam. Namun secara

\footnotetext{
${ }^{1}$ Atem, “Ancaman Cyber Pornography Terhadap Anak-Anak,” Jurnal Moral Kemasyarakatan 1, no. 2 (2016): 111, https://doi.org/https://doi.org/10.21067/jmk.v1i2.1529.

2 Diah Ningrum, "Kemerosotan Moral Di Kalangan Remaja: Sebuah Penelitian Mengenai Parenting Styles Dan Pengajaran Adab Diah Ningrum Sekolah Menengah Islam Terpadu (SMIT) Al Marjan," Unisia XXXVII, no. 82 (2015): 19, https://journal.uii.ac.id/Unisia/article/view/10491/8171.

3 Tian Wahyudi, "Strategi Pendidikan Akhlak Bagi Generasi Muda Di Era Disrupsi," TA'LIM: Jurnal Studi Pendidikan Islam 3, no. 2 (2020): 23, https://doi.org/https://doi.org/10.29062/ta'lim.v3i2.

${ }^{4}$ Rahayu Marini Hakim, "Murid Lecehkan Guru Di Instagram, Psikolog: Krisis Moral," accessed November 23, 2020, https://republika.co.id/berita/qdkigs282/murid-lecehkan-guru-di-instagram-psikologkrisis-moral.

5 Sri Salmah, "Perilaku Vandalisme Remaja Di Yogyakarta," Media Informasi Penelitian Kesejahteraan Sosial 39, no. 1 (2015): 16, https://doi.org/10.31105/mipks.v39i1.534.

6 Eryzal Novrialdy, "Kecanduan Game Online Pada Remaja: Dampak Dan Pencegahannya," Buletin Psikologi 27, no. 2 (2019): 149, https://doi.org/10.22146/buletinpsikologi.47402.

${ }^{7}$ Nur Ika Fatmawati, "Literasi Digital, Mendidik Anak Di Era Digital Bagi Orang Tua Milenial," Jurnal Politik Dan Sosial Kemasyarakatan 11, no. 2 (2019): 129, http://ejurnal.unisda.ac.id/index.php/MADANI/article/view/1602. 
umum, hal tersebut dapat dikelompokan ke dalam dua pendapat, yakni pendapat yang memahaminya sebatas "qital" atau "harb" yang berarti "perang" sebagaimana pengertian ini juga banyak dipahami Barat, $^{8}$ namun tidak sedikit juga yang memaknainya secara lebih luas, misalnya pengertian yang menunjukan bahwa jihad sebagai bentuk perjuangan seorang mukmin demi menggapai rida Allah atau meninggikan agama Allah dan jihad dalam konteks ini dapat dilakukan dengan berbagai bidang, seperti social, pendidikan, ekonomi, hukum, politik dan lain-lain.

Dua pengertian secara umum tentang jihad di atas, perlu ditempatkan pada konteksnya. Jihad dalam pengertian pertama dengan makna "perang" sebenarnya lebih bersifat defensif dan protektif, karenanya memiliki syarat-syarat dan etika tersendiri dalam implementasinya. Sementara jihad dalam pengertian kedua menuntut peran serta setiap mukmin dalam menyebarkan kebaikan dan menghadapi berbagai kemungkaran dengan kemampuan yang dimiliki masing-masing, termasuk dalam kaitan ini adalah dalam bidang pendidikan.

Berdasarkan pemikiran di atas, dalam artikel ini penulis mengkaji bagaimana urgensi jihad dalam bidang pendidikan dan peran umat dalam mengaktualisasikannya. Spirit perjuangan yang terkandung dalam konsep jihad perlu digali agar dapat diaktualisasikan dalam bidang pendidikan di era digital. Studi yang mengkaji secara khusus mengenai ini belum banyak dilakukan. Padahal umat Islam dalam hal ini, perlu memahami konsep jihad yang lebih luas dari hanya sebatas makna perang. Umat Islam perlu memahami urgensitas dan perannya masing-masing dalam membangun pendidikan. Tanggung jawab pendidikan adalah tanggung jawab kolektif semua elemen umat. Hal tersebut karena generasi muda sebagai subjek utama pendidikan, hidup di tengah-tengah umat, baik dalam lingkup kecil yaitu di rumah yang merupakan tanggung jawab keluarga, maupun di tengah-tengah masyarakat, yang merupakan tanggung jawab umat. Dengan pemahaman yang utuh terkait konsep jihad dan korelasinya dengan peran penting masing-masing individu muslim dalam bidang pendidikan, harapanya akan mampu mengantarkan generasi muda muslim menjadi generasi khairu ummah.

${ }^{8}$ Loue Sana, "AIDS Jihad: Integrating the Islamic Concept of Jihad with HIV Prevention Theory," Journal of Health Care for the Poor and Underserved 22, no. 33 (2011): 725, https://doi.org/http://dx.doi.org/10.1353/hpu.2011.0095.

Tribakti: Jurnal Pemikiran Keislaman

Volume 32, Nomor 1, Januari 2021 


\section{Metode}

Dalam penelitian ini, penulis menggunakan jenis penelitian studi pustaka (library research). Oleh sebab itu, sumber datanya diambil dari berbagai sumber data tertulis ${ }^{9}$ yang relevan dengan topik kajian penelitian. Sumber data yang digunakan dalam penelitian ini, yaitu sumber data primer dan sekunder. Sumber data primer meliputi buku-buku tafsir, fiqih jihad, serta artikel-artikel jurnal yang berkaitan dengan jihad dan pendidikan. Sementara sumber-sumber sekunder diambil dari buku-buku, artikel-artikel jurnal dan website yang berisi pendapat pakar atau praktisi atau survei yang relevan dengan objek kajian penelitian.

Setelah penulis mengumpulkan data-data pustaka yang dibutuhkan, penulis melakukan kategorisasi dan pemilahan data-data yang relevan. Data-data tersebut kemudian dianalisis menggunakan teknik analisis isi (content analysis). Dengan teknik analisis isi ini penulis menganalisis tema-tema utama berkaitan dengan jihad, pendidikan dan problematikanya dalam konteks kekinian dari berbagai literatur yang telah dipilih dan dipilah. Selanjutnya, penulis mendeskripsikan secara rinci dan argumentatif terhadap data-data tersebut untuk disajikan dalam tulisan ini.

\section{Hasil dan Pembahasan}

\section{Makna dan Urgensi Jihad Pendidikan}

Secara etimologis kata jihad berasal dari kata jahd yang berarti usaha, jerih payah, dan kesukaran. Jihad juga berasal dari kata juhd yang berarti kemampuan ${ }^{10}$ atau kekuatan. Menurut Yusuf Al-Qardhawy, kata "jihad” merupakan isim masdar dari kata “jâhada-yujâhidu-jihadan-wa mujahadatan” artinya mencurahkan segala kemampuan dan tenaga. ${ }^{11}$ Selanjutnya kata "jâhada" tersebut bila disandingkan dengan kata " $f i$ sabilillah", maka bermakna, "berjuang atau berperang di jalan Allah."12 Dalam Alquran sendiri, sebagaimana dituturkan Al-Qardhawy, bahwa arti jihad sebagian besar bermakna, "mengerahkan segala kekuatan untuk menjaga dan menyebarkan dakwah Islamiyyah. ${ }^{13}$

\footnotetext{
${ }^{9}$ Mestika Zed, Metode Penelitian Kepustakaan (Jakarta: Yayasan Pustaka Obor Indonesia, 2014), n. 3.

${ }^{10}$ M. Quraish Shihab, Wawasan Al-Quran (Bandung: PT Mizan Pustaka, 2007), bk. 661.

${ }^{11}$ Yusuf Al-Qardhawi, Figh Al-Jihad: Dirasah Muqaranah Liahkamihi Wa Falsafatihi Fi Doui Al-Quran Wa As-Sunnah, 4th ed. (Kairo: Dar Al-Kutub Al-Mishriyyah, n.d.), 55.

${ }_{12}$ A.W. Muanawwir, Kamus Al-Munawwir Arab-Indonesia. (Surabaya: Pustaka Progresif, 1997), 217, $\mathrm{Su}$.

13 Al-Qardhawi, Fiqh Al-Jihad: Dirasah Muqaranah Liahkamihi Wa Falsafatihi Fi Doui AlQuran Wa As-Sunnah, 62. 
Adapun secara terminologis, bila dilihat dari berbagai pendapat pakar didapat pengertian yang cukup beragam. Raghib Al-Isfahani misalnya, memaknai jihad dengan mengerahkan segala kekuatan untuk memerangi musuh, yang dalam hal dibagi dalam tiga pengertian, yaitu: 1) memerangi musuh yang nyata; 2) memerangi setan dan; 3) memerangi hawa nafsu. ${ }^{14}$ Muhammad Chirjin, setelah mencermati 28 ayat tentang jihad dalam konteks perjuangan memaknai jihad sebagai, "perjuangan orang beriman dengan mencurahkan kemampuan moril dan materil berupa tenaga, pikiran maupun harta benda untuk menegakkan agama Allah dan meninggikan kalimat-Nya". ${ }^{15}$ Al-Qardhawi juga dalam bukunya fiqh al-jihad menjelaskan macam-macam jihad dalam berbagai bidang, seperti jihad lisan wal bayan; jihad madani yang meliputi bidang ilmu pengetahuan, social, ekonomi, pendidikan, kesehatan, lingkungan; dan jihad dalam bentuk fisik atau militer. $^{16}$

Dari beragam penjelasan di atas dapat dipahami bahwa jihad secara prinsipil merupakan upaya serius dan sungguh-sungguh yang dilakukan oleh seorang mukmin dengan segala kemampuan atau modal yang dimilikinya baik berupa fisik, intelektual, harta, bahkan nyawa dengan cara-cara yang sesuai dengan tuntunan syariat demi menggapai rida Allah SWT. Dengan demikian, jihad hakikatnya dapat diterapkan dalam semua aspek kehidupan kaum muslim dalam rangka menggapai rida Allah atau meninggikan kalimat Allah SWT.

Berdasarkan pengertian di atas, bila disandingkan dengan term pendidikan, maka maknanya menjadi lebih spesifik, yakni jihad khusus dalam bidang pendidikan. Dalam hal ini secara lebih rinci dapat diartikan, bahwa jihad dalam bidang pendidikan merupakan upaya serius dan sungguh-sungguh yang dilakukan oleh seorang mukmin dengan segala modal yang dimilikinya demi terselenggaranya pendidikan yang berkualitas yang diperuntukan bagi umat Islam dengan cara-cara yang sesuai dengan tuntunan syariat demi menggapai rida Allah SWT”. Oleh karenanya tepatlah yang dikatakan Hilmy Bakar yang dikutip oleh Ramlan dkk, bahwa aktivitas pendidikan yang

14 Shihab, Wawasan Al-Quran, 668. Menurutnya tiga macam makna jihad tersebut tercakup dalam firman Allah Swt. dalam Q.S. Al-Hajj [22]:78 dan Q.S. Al-Baqarah [2]: 218), dan hadits Nabi Saw.: "Jahidu Ahwa akum kama tujahiduna 'ada'akum" (Berjihadlah menghadapi nafsumu sebagaimana engkau berjihad menghadapi musuhmu.".

15 Muhammad Chirzin, "Reaktualisasi Jihad Fi Sabil Allah Dalam Konteks Kekinian Dan Keindonesiaan," Ululmuna X, no. 1 (2006): 60, https://doi.org/https://doi.org/10.20414/ujis.v10i1.432.

16 Al-Qardhawi, Fiqh Al-Jihad: Dirasah Muqaranah Liahkamihi Wa Falsafatihi Fi Doui AlQuran Wa As-Sunnah.

Tribakti: Jurnal Pemikiran Keislaman

Volume 32, Nomor 1, Januari 2021 
dijalankan secara seirus dan sungguh-sungguh dengan tujuan meninggikan kalimat Allah sejatinya termasuk juga kepada jihad. ${ }^{17}$

Dalam pendidikan Islam, pembangunan manusia didik diarahkan kepada pemeliharaan fithrah dan pengembangan berbagai potensi baik yang dimilikinya, tidak hanya semata-mata meningkatkan aspek intelektualitas atau keterampilan, namun juga menghendaki kepribadian dengan akhlak mulia dengan semangat teologis, yakni mencari ridha Allah SWT. Tujuan pendidikan Islam itu sendiri sejatinya merupakan bentuk aktualisasi tujuan hidup manusia, yaitu penghambaan secara total kepada Allah SWT. Hal ini sebagaimana tertera dalam Q.S. Al-Dzariyat ayat 56: "wa ma khalaqtu aljinna wa al-insa illa liya'budun”, yang berarti, “tidaklah aku ciptakan jin dan manusia melainkan untuk beribadah kepada ku."

Untuk mewujudkan pedidikan yang baik dan berkualitas dibutuhkan kesungguhan dan keseriusan dalam penyelenggaraannya. Spirit kesungguhan dan keseriusan tersebut tekandung dalam makna jihad, yang memuat siprit dan semangat teologis yang kuat. Hal ini karena konsekuensi dari spirit tersebut adalah ganjaran yang besar dari Allah SWT. sebagaimana terdapat dalam Al-quran maupun hadits Nabi Saw. Oleh karenanya, jihad sebagai spirit dan dipadankan dengan pendidikan sebagai perangkat dan bentuk aktualisasinya dalam rangka membangun generasi dan masyarakat yang berkualitas di era ini menjadi hal yang penting dan perlu diprioritaskan oleh umat Islam.

Hadirnya berbagai problem pendidikan Islam dewasa ini, semakin menguatkan akan arti penting jihad pendidikan. Pesatnya perkembangan teknologi informasi telah banyak memberikan kemudahan bagi manusia, namun di sisi lain kehadirannya juga menyertakan beragam problem-problem yang perlu diselesaikan dunia pendidikan. Masalah-masalah tersebut mencakup banyak hal, mulai dari pemikiran, budaya dan gaya hidup, moral, serta kualitas guru dan ketersediaan infrastruktur pendidikan yang belum memadai.

Dalam hal pemikiran, generasi umat dihadapkan beragam paham pemikiran yang tanpa disadari dapat menggerus jati diri seorang muslim, seperti liberalisme yang mengusung kebebasan berpikir dan berekspresi tanpa batas, sekularisme yang memandang bahwa agama hanya semata-mata urusan individu dengan Tuhan sehingga

${ }^{17}$ Ramlan Ramlan, Tengku Erwinsyahbana, and Nurul Hakim, "The Concept of Jihad In Islam," IOSR Journal of Humanities and Social Science 21, no. 09 (2016): 41, https://doi.org/10.9790/08372109073542. 
memisahkan agama dari masalah sosial-politik, pluralisme agama yang mengampanyekan kepada masyarakat muslim untuk membenarkan secara teologis agama lain dengan dalih toleransi, dan materialisme yang mengarahkan pada keyakinan bahwa puncak keberhasilan dalam hidup adalah pencapaian materi (seperti kekayaan, pangkat-jabatan, popularitas dan lain-lain). Paham-paham tersebut jelas bertentangan dengan ajaran Islam sebagaimana dalam hal ini Majelis Ulama Indonesia juga melarang tiga paham pertama, yakni liberalisme, sekularisme, dan pluralisme agama. ${ }^{18}$ Sementara materialisme bertentangan karena menjadikan materi-keduniaan sebagai tujuan utama hidup. Paham tersebut jugalah yang mengarahkan generasi umat pada budaya dan gaya hidup hedonis, konsumtif, dan budaya instan yang disadari atau tidak semakin menjadikan generasi umat terlena dan semakin apatis terhadap tugas dan kewajiban mereka. ${ }^{19}$

Adapun berkaitan dengan masalah moral yang juga menjadi PR bersama perlu diperhatikan dan diselesaikan. Kemudahan akses terhadap berbagai hal di dunia maya merupakan tantangan tersendiri bagi pendidikan akhlak. Rentetan masalah yang semakin banyak dan meluas. Endah Triastuti (dkk) memberikan data-data hasil studi berbagai institusi yang menunjukan masalah serius berkenaan dengan dampak media virtual terhadap anak-anak. Data-data tersebut antara lain: 1) sebanyak 80 juta anakanak telah mengakses pornografi secara online dan jumlahnya semakin meningkat sampai 90\% (data hasil studi Badan Pusat Statistik tahun 2010-2014); 2) sebanyak 932 khasus yang menjadikan anak-anak sebagai target utama pornografi dan kejahatan dunia maya (data hasil studi dari Komisi Perlindungan Anak Indonesia tahun 2011-2014); 3) sebanyak 35 anak mengalami ekpsploitasi seksual di ranah maya (Data hasil studi End Child Prostitution, Child Pornography \& Trafficking Of Children For Sexual Purposes Indonesia tahun 2010-2015); 4): sebanyak 2 dari 10 anak Indonesia yang mengakses sosial media mengalami perundungan maya (data hasil studi Indonesia Sejiwa Foundation); 5) kebohongan yang dilakukan anak-anak dan remaja berkenaan dengan usia mereka demi untuk mengakses situs tertentu (Studi Komenkominfo \& UNICEF pada tahun 2014). ${ }^{20}$ Sementara berkaitan dengan ketersediaan guru dan infrastruktur

18 Majelis Ulama Indonesia, "Pluralisme, Liberalisme, Dan Sekularisme Agama," Himpunan Fatwa MUI, 2005.

${ }^{19}$ Wahyudi, "Strategi Pendidikan Akhlak Bagi Generasi Muda Di Era Disrupsi," 23.

20 Tian Wahyudi, "Paradigma Pendidikan Anak Dalam Keluarga Di Era Digital (Perspektif $\begin{array}{lllllll}\text { Pendidikan } \quad \text { Islam)," } & \text { Ri'ayah } & \text { 4, } & \text { no. } & 01 & \text { (2019): } & 36 \text {, }\end{array}$ https://doi.org/https://doi.org/10.32332/riayah.v4i01.1489. Tribakti: Jurnal Pemikiran Keislaman Volume 32, Nomor 1, Januari 2021 
pendidikan juga masih merupakan permasalahan tersendiri yang belum tuntas. Permasalahan lain terkait guru berkaitan dengan persebarannya, yang disinyalir oleh pengamat pendidikan masih terjadi kesenjangan antara kota dan desa, yang dianggap guru di desa terpencil lebih sedikit dan kurang memadai dibanding di kota. Hal yang sama juga berkaitan dengan masalah sarana prasarana. Di daerah-daerah terpencil tidak sedikit masih terdapat sarana dan prasarana yang belum memadai bahkan kurang layak untuk digunakan, terutama daerah-daerah pedesaan. Berkaitan dengan ruang kelas misalnya, ketersediaannya dalam kondisi baik masih di bawah 50\%. Lebih rinci lagi berdasarkan data BPS untuk tahun ajaran 2018/2019 fasilitas dengan kondisi baik pada jenjang SD hanya 27,40 \%; jenjang SMP 31,28\%; jenjang SMA 44,53\%; dan jenjang SMK $47,35 \% .^{21}$ Dalam kotents saat ini, infrastruktur telekomunikasi dan persebaran jaringan internet juga masih menjadi kendala tesendiri di tengah pemberlakukan pembelajaran di rumah pada masa pandemi.

Paparan permasalahan di atas menunjukan perlunya perhatian serius pemerintah dan masyarakat muslim secara khusus dalam bidang pendidikan. Berbagai problem yang terjadi menuntut peran serta semua elemen umat untuk berperan aktif dalam berjihad dengan mengerahkan dan mencurahkan segala potensi dan kemampuan yang dimiliki untuk berjuang membangun generasi masa depan umat. Tanpa adanya kerja sama semua pihak sulit untuk bergerak maju membentuk generasi umat yang handal. Oleh karenanya, jihad seorang muslim dalam bidang pendidikan dengan modal yang dimilikinya adalah upaya nyata bagi penyelesaian masalah umat.

\section{Peran Umat dalam Mengaktualisasi Jihad Pendidikan}

Untuk membangun pendidikan yang berkualitas, dibutuhkan peran kolaboratif semua komponen masyarakat. Peran tersebut dapat dimaknai dengan dua pengertian, yakni perannya sebagai seorang muslim yang bertanggung jawab terhadap kualitas dirinya sendiri dan keluarganya; dan perannya sebagai muslim dalam komunitas masyarakat muslim dalam rangka membangun kualitas generasi umat. Untuk itu umat Islam perlu menempatkan pendidikan sebagai tanggung jawab individu dan sosial.

Semangat ukhuwaah Islamiyyah adalah modal dasar yang perlu diaktualisasikan bagi terbangunnya sinergitas semua kalangan. Ukhuwwah Islamiyyah perlu dipetakan dan diaktualisasikan dalam bentuk kerjasama setiap bidang, baik itu bersifat individu

21 Badan Pusat Statistik, Potret Pendidikan Indonesia; Statistik Pendidikan Indonesia (JakartaIndonesia: Badan Pusat Statistik, 2019), 18. 
dengan menjalankan perannya masing-masing dalam aspek pendidikan, maupun dengan lebih terstruktur dan sistematis dalam bentuk komunitas atau organisasi.

Dalam upaya meningkatkan peran setiap individu muslim dalam meningkatkan pendidikan, diperlukan pemahaman terhadap berbagai bentuk aktualisasi jihad dalam pendidikan. Berikut ini beberapa bentuk jihad pendidikan dengan mengacu kepada kompenen-komponen pendidikan dan upaya-upaya yang terkait dengannya yang dapat diaktualisasikan saat ini.

\section{Jihad Melawan Hawa Nafsu}

Abuddin Nata mengungkapkan, terdapat 37 kata "hawa” yang terdapat dalam Al-Quran yang mengandung beragam makna. Pertama, mengandung pengertian kebinasaan. Hal tersebut, sebagaimana yang terdapat pada Q.S. Thaha ayat 81, yang berbunyi, “...wa man yahlil 'alaihi ghadhobiy fa qad hawa, artinya, "dan barang siapa yang ditimpa kemurkaan-Ku, maka binasalah ia. Kedua, berkaitan dengan sifatnya yang tidak mau menerima kebenaran, sebagaima yang terkandung dalam Q.S. Al-Maidah ayat 70 yang berbunyi, “...kullama jaa hum Rasulun bima la tahwa anfusuhum, fariyqan kadzabu wa fariyqan yaqtulun, artinya, “... setiap datang seorang Rasul kepada mereka dengan membawa apa yang tidak diingini oleh hawa nafsu mereka, (maka) sebagian dari rasu-rasul itu mereka dustakan dan sebagian yang lain mereka bunuh.

Ketiga, berkaitan dengan makna yang menjadi sasaranya, yakni menyesatkan manusia, karenya diperingatkan untuk tidak mengikutinya. Hal ini sebagaimana tercantum dalam Q.S. Ahad ayat 26 yang berbunyi, “...wa la tattabi' al-hawa fa yudilluka 'an sabilillah..." yang berarti, "dan janganlah kamu mengikuti hawa nafsumu, karena dapat menyesatkanmu dari jalan Allah. Berkaitan dengan makna itu juga dapat dilihat dalam Q.S. An-Nisa ayat 135, Q.S. Al-Maidah ayat 48 dan 150, Q.S. Al-An'am ayat 150. Keempat, berkaitan dengan lawannya, yaitu al-haqq (kebenaran). Hal tersebut terkandung dalam Q.S. Shad ayat 26 yang berbunyi, "ya Dawud inna ja'alnaka khalifatan fi al-ardhi fahkum baina an-Nas bi al-haqqi wa la tattabi'I alhawa fayudilluka 'an sabilillah..., yang berarti, "Hai Daud.., sesungguhya kami menjadikanmu khalifah di muka bumi, maka berilah keputusan (perkara) diantara manusia dengan dan janganlah kamu mengikuti hawa nafsu, karena dia dapat menyesatkanmu dari jalan Allah..." Kelima, berkaitan dengan pahala bagi orang yang mampu mengendalikannya. Hal tersebut sebagaimana yang termuat dalam Q.S AnNazi' at ayat 40-41 yang berbunyi, "wa amma man khafa Rabbihi wa naha an-nafsa 'an 
al-hawa fa inna al-jannata hiya al-ma'wa" artinya, "dan adapun orang-orang yang takut kepada kebesaran Tuhannya dan menahan diri dari (keinginan) hawa nafsunya, maka sungguh, surgalah tempat tinggal (nya)." Keenam, berkaitan dengan akibat mengikuti hawa nafsu, yakni kerusakan dan kebinasaan. Hal tersebut sebagaimana yang terkandung dalam Q.S. Al-Mukminun ayat 71 yang berbunyi, "wa law ittaba'a al-haqq ahwaahum lafasadat as-samawati wal ardh wa man fihinna..." artinya, "kalaulah kebenaran itu menurut hawa nafsu mereka, pasti binasalah langit dan bumi ini, dan semua yang ada di dalamnya..."22

Jihad melawan hawa nafsu merupakan jihad yang memerlukan daya dan upaya yang kuat dalam mengendalikan diri sendiri dengan tujuan mendapat ridha Allah. Seorang mujahid adalah orang yang berjihad (berjuang) mengendalikan dirinya (nafsunya) karena Allah, demikianlah sabda Nabi SAW sebagaimana diriwayatkan Imam Ahmad. Hal ini karena hawa nafsu memang perlu dilawan karena sifatnya yang dapat menjerumuskan manusia kepada dosa, tindakan-tindakan keji dan munkar, baik itu berupa ucapan, perbuatan, maupun perbuatan hati manusia. Jika kemauan hawa nafsu terus dituruti dan tidak dikendalikan, maka ia dapat mendatangkan kerusakan bagi diri sendiri maupun orang lain.

Jihad melawan hawa nafsu adalah keniscayaan bagi seorang muslim. Tanpa mengawali dengan pengendalian terhadap hawa nafsu, sulit baginya untuk melakukan jihad dengan cara-cara lain. Keberadaannya yang terdapat pada diri setiap manusia, menjadi awal pintu masuk pengaruh setan. Oleh karenanya, dia dapat hadir dalam beragam bentuknya kepada setiap manusia tanpa mengenal usia tua atau muda; tanpa mengenal status sosial kaya-miskin, jabatan tinggi-rendah; tanpa mengenal jenis kelamin pria atau wanita; tanpa mengenal profesi pedagang, petani, guru-dosen, pegawai dan lain-lain

Jihad melawan hawa nafsu pada hakikatnya merupakan bentuk pendidikan bagi diri sendiri sepanjang masa. Setiap individu muslim dituntut untuk terus berjuang mengendalikannya. Upaya untuk meningkatkan kemampuan dalam mengendalikan hawa nafsu dapat dimulai dengan terus meningkatkan ilmu, iman, serta amal sholeh. Seorang muslim harus menyadari keberadaan nafsunya agar dapat dikendalikan oleh akal dan hatinya yang terbimbing oleh ilmu dan imannya.

${ }^{22}$ Abuddin Nata, Tafsir Ayat-Ayat Pendidikan (Jakarta: Rajawali Pers, 2014), 140-41. 
Dalam konteks pendidikan, mengendalikan diri agar senantiasa dalam ketaatan kepada Allah dan fokus kepada tujuan pendidikan Islam yakni menjadi hamba Allah seutuhnya merupakan hal pokok bagi seorang muslim. Pengendalian diri perlu dilakukan oleh semua insan pendidikan, baik orang tua, guru, peserta didik, maupun kaum muslimin secara umum. Oleh karenanya, kemampuan mengendalikan diri sendiri merupakan hal yang harus dilakukan secara istiqamah sepanjang hayat.

\section{Jihad Bagi Orang Tua dalam Pendidikan}

Keluarga merupakan intitusi pendidikan pertama dan utama. Untuk itu, peran dan tanggung jawab keluarga terhadap pendidikan generasi muda sangatlah besar. Tugas mendidik, belum selesai hanya dengan menyekolahkan anak ke lembaga pendidikan

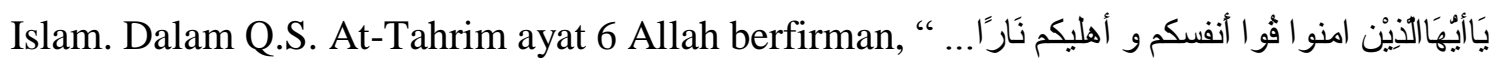
" yang berarti, "hai orang-orang beriman peliharalah dirimu dan keluargamu dari api neraka". Sufyan As-Sauri mengatakan bahwa makna qu anfuskum wa ahlikum nara" pada ayat tersebut adalah "didiklah dan ajarilah mereka". ${ }^{23}$ Sementara Muqatil menjelaskan, bahwa setiap muslim memiliki kewajiban untuk mengajari keluarganya, kerabatnya dan juga budaknya berkenaan tentang segala yang difardhukan Allah dan mengajarkan untuk menjauhi segala yang hal yang dilarang-Nya. ${ }^{24}$ Dengan demikian, keluarga memiliki tanggung jawab besar terhadap pembangunan pendidikan generasi muda.

Bagi orang tua, anak adalah amanah dari Allah. Amanah merupakan tanggung jawab orang tua terhadap anak berkaitan dengan kehidupannya. Amanah tersebut salah satunya adalah kewajiban untuk mengupayakan secara maksimal agar anak mengenali dirinya sebagai hamba Allah dan sebagai khalifatullah fi al-ardh (wakil Allah di muka bumi) yang merupakan tujuan dari penciptaan manusia. Tujuan tersebut tentu sulit tercapai tanpa menghadirkan pendidikan yang tepat. Oleh karenanya, pendidikan adalah syarat mutlak guna tercapainya tujuan tersebut.

Untuk merealisasikan tanggung jawab tersebut, orang tua perlu berjihad, yakni berupaya sekuat tenaga dengan kemampuan yang dimiliki untuk membangun pendidikan yang baik dan tepat bagi anak-anaknya. Adapun ikhtiar tersebut dapat dilakukan antara lain dengan: 1) senantiasa mendoakan anak; 2) menjadi teladan yang

${ }^{23}$ Abu Fida bin Isma'il bin Katsir, E-Book: Tafsir Ibnu Katsir (Omel kitab.net, n.d.).

${ }^{24}$ Katsir.

Tribakti: Jurnal Pemikiran Keislaman

Volume 32, Nomor 1, Januari 2021 
baik, dan 3) memberikan pendidikan yang tepat; 4) membangun lingkungan yang baik dan menjauhkannya dari lingkungan yang buruk.

Mendoakan anak adalah ikhtiar penting yang perlu dilakukan orang tua terhadap anaknya. Bagi seorang muslim, doa disamping sebagai ibadah, ia juga merupakan sarana penting untuk berkomunikasi dengan Allah. Allah senang terhadap hamba yang senantiasa berdoa kepada-Nya. Dengan dia bermohon kepada-Nya, hal itu menunjukan ketidakberdayaannya dan ketergantungan pada pertolongan-Nya. Sebagai orang tua, untuk menjalankan amanah dalam merawat dan mendidik anak, membutuhkan pertolongan Allah guna mencapai tujuan pendidikan yang diharapkan. Kemampuan manusia terbatas, sementara Allah Maha Kuasa terhadap makhluk-makhluknya. Oleh karenanya, upaya orang tua untuk senantiasa mendoakan anaknya agar menjadi shaleh merupakan upaya penting yang harus dilakukan orang tua dengan penuh kesungguhan demi tercapainya generasi shaleh.

Hal penting lainnya yang diperlukan orang tua dalam pendidikan adalah selalu berusaha menjadi pribadi yang baik yang dapat diteladani. Keteladan dalam pendidikan adalah keniscayaan. Mendidik anak harus dimulai dari mendidik diri sendiri. Hal ini karena, lingkungan keluarga adalah lingkungan yang paling dekat dengan anak-anak. Setiap sikap dan prilaku orang tua selalu menjadi perhatian utama bagi anak-anaknya.

Melalui keteladanan, orang tua juga dapat mengajarkan banyak hal kepada anakanaknya. Dengan keteladanan orang tua dapat mengajarkan anak dengan "mengajak" bukan "memerintah". Dengan "mengajak" artinya orang tua sudah melakukan sesuatu sebelum memerintahkannya kepada anak. Untuk mengajarkan shalat, puasa dan bentuk perilaku lainnya, orang tua harus melakukan perilaku itu terlebih dahulu, tidak cukup hanya dengan memerintah.

Selanjutnya, tanggung jawab orang tua terhadap anak adalah memberikan pendidikan aqidah, ibadah, akhlaq, rasio, dan jasmani. Pendidikan aqidah meliputi penanam Iman kepada Allah, para malaikat-Nya, kitab-kitab-Nya, rasul-rasul-Nya, hari akhir, takdir baik dan buruk. Sementara pendidikan ibadah meliputi pengajaran dan pelatihan tentang berbagai ritual ibadah khusus, seperti shalat, puasa, zakat, dan haji. Selanjutnya pendidikan akhlaq yaitu penanaman pada diri anak tentang sikap dan perilaku yang baik dalam hubungannya dengan diri sendiri, dengan orang tuanya, dengan masyarakat bahkan dengan makhluk Allah yang lain. Sementara pendidikan rasio adalah pembentukan dan proses peningkatan kemampuan intelektual anak dalam 
berbagai bidang yang berkaitan dengan rasio, seperti bidang matematika, alam, teknologi dan sebagainya. Adapun pendidikan jasmani yaitu pelatihan, pembiasaan dan perawatan anak guna mencapai kesehatan fisik yang prima, seperti dengan menjaga makan dan minum yang halal dan thayyib secara teratur, menjaga kebersihan dan berolahraga. Tanggung jawab pendidikan tersebut dapat dilakukan secara mandiri dan langsung oleh orang tua atau dengan dibantu lembaga pendidikan yang amanah dan memuat pendidikan di atas dengan cara memilihnya.

Disamping hal di atas, lingkungan anak juga menjadi upaya penting untuk diperhatikan dalam membangun pendidikan yang baik. Orang tua perlu menciptakan lingkungan yang baik dan menjaga anaknya dari pengaruh-pengaruh lingkungan yang buruk. Termasuk dalam konteks kekinian adalah pengaruh media digital. Orang tua perlu mengawasi, membimbing dan mengarahkan anak dalam penggunaan media digital. Jangan sampai, media digital justru menjadi sarana terbentuknya perilaku negatif pada anak. Oleh sebab itu, penting bagi orang tua untuk juga sisi positif dan negatif media digital bagi anak-anaknya.

\section{Jihad Bagi Guru}

Dalam proses pendidikan, guru adalah salah satu komponen penting bagi tercapainya tujuan pendidikan. Menurut Syahidin, peran dan fungsinya tidak dapat digantikan, bahkan oleh kecanggihan teknologi apapun. ${ }^{25}$ Tidak dapat dipungkiri, bahwa kualitas pendidikan sangat banyak ditentukan dari kualitas gurunya. Pada dirinya terdapat tanggung jawab untuk mengantarkan para peserta didiknya kepada tujuan pendidikan yang telah dicitakan. Kedudukan guru begitu tinggi, sebagaimana yang dikatakan Imam Al-Ghazali:

Seorang yang berilmu dan kemudian bekerja dengan ilmunya, dia adalah orang besar di bawah langit. Dia seperti matahari yang menyinari orang lain dan dirinya sendiri. Dia seperti minyak kasturi yang wanginya bisa dinikmati orang lain dan dirinyapun tetap wangi. Siapa yang bekerja di bidang pendidikan, sesungguhnya ia telah memilih pekerjaan sangat penting dan terhormat. Oleh sebab itu, hendaknya ia memelihara adab dan sopan santun dalam menjalankan tugasnya tersebut. ${ }^{26}$

25 Syahidin, "The Teacher Education In Islamic Views: A Conceptual Analysis To Increase Teacher And Lecturer Professionalism Islamic Religious Education In Indonesia,” International Journal of Recent Scientific Research 8, no. $10 \quad$ (2017): https://doi.org/http://dx.doi.org/10.24327/ijrsr.2017.0810.0921.

${ }^{26}$ Toto Suharto, Filsafat Pendidikan Islam (Yogyakarta: Ar-Ruz, 2006), 119-20.

Tribakti: Jurnal Pemikiran Keislaman

Volume 32, Nomor 1, Januari 2021 
Seorang guru perlu berupaya keras untuk menjadi pendidik yang baik. Upayanya tersebut dalam mendidik masyarakat secara umum maupun generasi muda secara khusus agar semakin memahami Islam dan meningkatkan kualitas pribadi muslim adalah bentuk jihad ta 'limi seorang guru. Menurut Abdullah Nasih Ulwan, jihad ta 'limi adalah mengeluarkan segala daya dan upaya untuk membangun masyarakat muslim dari aspek ilmu, budaya, dan rasio, serta memberikan gambaran pemikiran Islam yang benar dan komprehensif berkenaan dengan alam semesta, kehidupan dan manusia. ${ }^{27}$

Adian Husaini mengatakan, "seorang guru adalah muaddib sekaligus ilmuan, karena tugas seorang guru yaitu menanamkan adab dan berbagi ilmu." 28 Untuk itu seorang guru perlu memiliki kompetensi yang menunjang dan sifat-sifat terpuji yang dapat diteladani. Berkaitan dengan kompetensi-kompetensi yang harus dikuasai, antara lain: 1) Penguasaan terhadap materi ajar secara komprehensif; 2) penguasaan terhadap strategi pendidikan Islam yang meliputi pemahaman tentang tujuan, pendekatan, metode, dan teknik pembelajaran; 3) penguasaan ilmu dan wawasan kependidikan; ${ }^{29}$ 4) Pemahaman tentang perkembangan anak; 5) Penguasaan dalam menggunakan berbagai media atau teknologi sebagai sarana pendidikan. Sementara berkaitan dengan sifat-sifat yang perlu dimiliki, yaitu: 1) bersifat Rabbani, yakni memiliki tujuan hidup, perilaku, dan pola pikir yang bersandar kepada Allah, mentaati Allah, dan menghamba hanya kepada Allah; 2) Ikhlas dalam menjalankan profesinya dengan senantiasa berharap untuk mendapatkan rida Allah; 3) sabar dalam mengemban amanah sebagai pendidik; 4) Senantiasa berkata jujur dan tidak menutup-nutupi informasi dan kebenaran ilmu; 5) bersikap adil terhadap peserta didik; 6) bersikap ramah dan mampu menciptakan keakraban; 7) menunjukan sikap semangat dan tidak mudah putus asa, baik dalam perilaku keseharian maupun dalam proses pembelajaran.

Yusuf al-Qardhawi mengatakan, bahwa jihad pendidikan (tarbawi) sangat penting demi membangun kader umat yang dapat mengembang tugas risalah yang istimewa ini, baik bagi dirinya maupun bagi alam semeseta. ${ }^{30}$ Pembangunan pendidikan tersebut tentu tidak mungkin terwujud tanpa kehadiran guru yang berkualitas. Hal ini karena peran guru dalam proses pendidikan memiliki kedudukan yang sangat vital.

\footnotetext{
${ }^{27}$ Abdullah Nasih Ulwan, Tarbiyyatul Awlad Fil Islam Jilid 1 (Beirut: Darusalam, 1992), 997.

28 Adian Husaini, Pendidikan Islam (Mewujudkan Generasi Gemilang Menuju Negara Adidaya 2045) (Depok: Yayasan Pendidikan At-Taqwa Depok, 2020), 238.

${ }^{29}$ Hamruni, Konsep Edutaiment Dalam Pendidikan Islam (Yogyakarta: Bidang Akademik UIN Sunan Kalijaga, 2008), 79.

${ }^{30}$ Al-Qardhawi, Fiqh Al-Jihad: Dirasah Muqaranah Liahkamihi Wa Falsafatihi Fi Doui Al-Quran Wa As-Sunnah, 238.
} 
Oleh karenanya, upaya kuat yang dilakukan guru untuk meningkatkan kompetensinya dalam rangka membangun generasi muda yang berkualitas merupakan bentuk jihad pendidikan yang harus terus ditingkatkan.

\section{Jihad Peserta Didik}

Islam menekankan urgensi belajar dan mencari ilmu bagi umat manusia sepanjang masa. Namun demikian, belajar dalam Islam tidak semata-mata ilmu untuk ilmu atau kepentingan pragmatis jangka pendek. Konsep lifelong education dalam Islam bervisi teologis. Semua proses pembelajaran yang dilakukan harus berlandaskan dan bertujuan pada misi ilahiyyah, yakni semakin mengenal Tuhan (ma'rifatullah) dan untuk mendaptkan rida Allah. Kewajiban menempatkan aktifitas belajar dan menuntut ilmu dengan visi teologis ini tertuang salah satunya dalam Q.S. al-Alaq ayat 1, yang berbunyi, "iqra' bismi rabbika al-ladzi khalaq (bacalah dengan menyebut nama Tuhanmu yang Menciptakanmu).” Banyak mufassir menjelaskan bahwa perintah membaca tanpa disertai objek yang dibaca pada ayat tersebut menunjukan arti yang luas tentang membaca (bisa diartikan membaca, mengkaji, menganalisis, meneliti, dan menelaah) berbagai objek kehidupan, seperti manusia, binatang, tumbuh-tumbuhan, langit, bumi, berbagai peristiwa kehidupan dsb. Proses belajar dengan membaca dalam arti yang luas tersebut harus senantiasa dihubungkan dengan dan atas nama Tuhan (bismirobbika al-ladzi khalaq). Dengan demikian, belajar akan semakin mendekatkan pelakunya pada pencipta-Nya.

Selanjutnya, Islam juga memberikan apresiasi yang tinggi bagi mereka yang bersungguh-sungguh dalam belajar dengan visi teologis. Hal tersebut sebagaimana sabda Nabi Saw., "man salaka thariqan yaltamisu fihi 'ilman sahhalallahu lahu thariqan ila al-jannah", yang berarti, "barang siapa yang berjalan guna mencari ilmu, maka Allah akan mudahkan jalan menuju surga" (HR. Ahmad dari Abu Hurairah). Sementara itu, bila dia berhasil dalam proses belajarnya, maka dia mendapatkan derajat yang tinggi. Hal tersebut sebagaimana tertera dalam firman Allah, "yarfa'illahu alladzina minkum, wa al-ladzina utul 'ilma, darojat."

Dalam proses pendidikan, peserta didik berkedudukan sebagai subjek didik. Oleh karenanya, seorang peserta didik harus memperhatikan tugas dan adab-adabnya dalam 
belajar dan menuntut ilmu. Asma Hasan Fahmi mengatakan, ada empat hal yang perlu diperhatikan bagi peserta didik dalam proses pendidikan, yaitu: ${ }^{31}$

a. Seorang peserta didik harus berupaya untuk membersihkan hatinya dari kotoran dan penyakit jiwa. Hal tersebut karena belajar merupakan ibadah yang menuntut kebersihan hati.

b. Peserta didik harus menanamkan dalam dirinya bahwa tujuan belajar dan menuntut ilmu yaitu untuk meraih keutamaan akhlak, mendekatkan diri kepada Allah, bukan untuk bermegah-megahan, terlebih mencari kedudukan.

c. Peserta didik harus memiliki ketabahan dan kesabaran dalam proses menuntut ilmu.

d. Peserta didik harus menghormati gurunya dan mendapatkan rida darinya.

Dari keempat hal di atas, Al-Abrasyi menambahkan sifat-sifat lainnya yang juga diperlukan bagi seorang peserta didik, misalnya: bersungguh-sungguh dan tekun dalam belajar, bahkan menurutnya bila diperlukan menggunakan waktunya siang dan malam demi memperoleh ilmu; senantiasa mengulang-ulang pelajaranya; dan bertekad untuk belajar sepanjang hayat. ${ }^{32}$ Disamping beberapa pendapat tersebut, penting juga bagi seorang peserta didik untuk: fokus dan konsentrasi sepenuhnya dalam belajar, sehingga tidak terjadi kegagalan dalam belajar; tawadu, baik terhadap guru maupun terhadap orang lain; dan belajar secara bertahap.

Memahami tugas dan kewajiban peserta didik untuk belajar dan menuntut ilmu merupakan hal utama yang perlu diketahui oleh peserta didik. Selanjutnya, peserta didik berusaha dengan segala kemampuan dan daya yang dimiliki untuk mengamalkannya dalam prosesnya mencari ilmu tersebut. Kesungguhan dan komitmennya dalam menuntut ilmu tersebut menunjukan dia berada dalam jalur fi sabilillah (di jalan Allah). Hal ini sebagaimana yang diriwayatkan Imam Tirmidzi, dari Anas bin Malik, bahwa Rasulullah SAW bersabda, "man kharaja fi thalab al-ilmi kana fi sabilillahi hatta yarji'a, yang artinya, "barang siapa yang keluar dalam rangka mencari ilmu, maka dia berada di jalan Allah sampai dia kembali. ${ }^{33}$

\footnotetext{
${ }^{31}$ Suharto, Filsafat Pendidikan Islam, 128.

32 Suharto, 128.

${ }^{33}$ Lidwa, Ensiklopedia Hadits, Kitab $9 \operatorname{Imam}($ E-BOOK) (Lidwa-Saltanera, n.d.).
} 


\section{Jihad Harta dalam Pendidikan}

Menurut Nawwaf Takruri, ada dua pengertian jihad dalam bidang harta, yaitu: a) pengertian umum, yang didefinisikan sebagai: sumbangan berupa harta untuk segala bidang kebaikan yang mengantarkan kepada keridaan Allah, seperti membantu fakir miskin, membangun masjid dan lain-lain. Pada prinsipnya, yaitu setiap sumbangan harta yang manfaatnya dapat dirasakan oleh sebagian kaum muslimin atau perseorangan; dan b) pengertian khusus, yang berarti sumbangan berupa harta untuk mendukung bidangbidang yang terkait dengan jihad militer. ${ }^{34}$

Sementara terkait dengan jihad pendidikan, Yusuf Al-Qardhawi mendefinisikannya dengan jihad yang dilakukan dengan pendirian sekolah-sekolah yang mengajarkan kaum muslimin sesuatu yang dapat memelihara identitas mereka dan menanamkan cinta kepada agama, bangsa, dan negara sehingga mereka tidak melampaui batas terhadap semua hal tersebut. Selain itu juga pemberian kesempatan kepada mereka yang cerdas agar dapat belajar ke jenjang yang lebih tinggi. ${ }^{35}$

Dari dua pendapat di atas dapat dipahami, bahwa jihad harta dalam bidang pendidikan yaitu dengan menafkahkan atau memberikan harta benda yang dimiliki untuk mencari rida Allah guna terselenggaranya kegiatan pendidikan yang berlandaskan ajaran Islam. Pendidikan yang dimaksud tentu tidak hanya pendidikan formal, termasuk juga di dalamnya pendidikan nonformal seperti Taman Pendidikan Al-Quran yang diselenggarakan di masjid-masjid, pendidikan pesantren non formal dsb. Adapun bentuknya dapat berupa: 1) mempersiapkan dana bagi kepentingan guru-guru yang berkualitas agar mereka tercukupi kehidupannya dan fokus untuk mendidik generasi muda muslim; 2) menyediakan infrastruktur atau sarana-pra sarana pendidikan; dan 3) memberikan biaya pendidikan bagi generasi muda muslim berbakat untuk pengembangan dirinya agar menjadi pribadi berkualitas sehingga dapat bermanfaat bagi umat kelak.

Guru adalah komponen utama bagi berjalannya proses pendidikan. Namun demikian, kenyataannya masih banyak di daerah terpencil yang memiliki keterbatasan tenaga pengajar. Bahkan tidak sedikit, guru yang mengajar dengan sukarela. Oleh

${ }^{34}$ Khusniati Rofiah and Moh. Munir, "Jihad Harta Dan Kesejahteraan Ekonomi Pada Keluarga Jamaah Tabligh: Perspektif Teori Tindakan Sosial Max Weber,” Justicia Islamica: Jurnal Kajian Hukum Dan Sosial 16, no. 1 (2019): 200, https://doi.org/10.21154/justicia.v16i1.1640.

35 Al-Qardhawi, Fiqh Al-Jihad: Dirasah Muqaranah Liahkamihi Wa Falsafatihi Fi Doui AlQuran Wa As-Sunnah, 238.

Tribakti: Jurnal Pemikiran Keislaman

Volume 32, Nomor 1, Januari 2021 
karena itu, menyiapkan pembiayaan bagi guru-guru merupakan upaya penting bagi terselenggaranya pendidikan.

Membangun sarana-prasarana pendidikan yang baik dan memadai termasuk komponen penting dalam proses pelaksanaan kegiatan pembelajaran. Dengan adanya sarana dan prasarana pendidikan, pendidik dan peserta didik akan dimudahkan dalam proses pembelajaran. Bangunan sekolah, perpustakaan, buku-buku, alat-alat peraga, alat-alat praktek, alat tulis menulis merupakan deretan sarana-prasaran pendidikan yang dibutuhkan guru dan murid dalam kegiatan belajar. Dalam konteks saat ini, termasuk media digital, baik itu yang berbentuk audio, visual dan audio visual juga menjadi kebutuhan tersendiri yang tidak dapat dikesampingkan.

Di samping saran-prasarana pendidikan, memberikan biaya sekolah bagi kaum muslimin yang membutuhkan juga merupakan bentuk lain dari upaya membangun kualitas genarasi muslim. Tidak sedikit pula kalangan muda muslim saat ini yang memiliki bakat namun masih kesulitan untuk mengakses pendidikan yang baik karena permasalahan ekonomi. Hal ini menunjukan bahwa pembiayaan bagi generasi muda agar mendapatkan pendidikan yang baik, masih sangat relevan untuk dilakukan.

\section{Jihad Pendidikan Melalui Media Virtual}

Setiap muslim tidak ada batasan untuk menggunakan sarana dan media apapun untuk melakukan edukasi terhadap masyarakat. Dengan kemampuan atau modal yang dimiliki, setiap individu dapat menebarkan kebaikan dan mencegah keburukan (amar ma'ruf nahi munkar) dengan beragam cara dan pendekatan dengan tetap memperhatikan ajaran dan nilai nilai Islam. Hanya saja untuk saat ini, kedudukan teknologi informasi dalam kehidupan masyarakat modern tidak hanya sebatas sebagai pelengkap, namun sudah menyatu dan tidak terpisahkan. Saat ini internet sudah menjadi media yang sangat mudah, bahkan di Indonesia sendiri sebagaimana yang dilaporkan "We Are Social” per Januari 2020 terdapat 175,4 juta pengguna internet aktif di Indonesia dari total populasi 272,1 juta jiwa, yang itu artinya 64\% masyarakat Indonesia telah mengakses dunia maya. ${ }^{36}$ Dengan demikian, penting kiranya menggunakan media virtual untuk dijadikan sarana dan media pendidikan sebagai upaya mencerdaskan kehidupan umat.

Namun demikian, di sisi lain sebagaimana telah dijelaskan di awal, bahwa media online tidak hanya menyajikan konten atau informasi positif, namun banyak juga

${ }^{36}$ Simon Kemp, “DIGITAL 2020: INDONESIA,” n.d., https://datareportal.com/reports/digital2020-indonesia. 
konten-konten yang jauh dari nilai-nilai edukatif, bahkan sangat merusak, seperti pornogafi, perudungan maya, berita hoax, konten kekerasan, beragam pemikiran yang merusak jati diri muslim dan lain-lain. Disamping itu, media juga seringkali dijadikan oleh pihak-pihak tertentu yang tidak senang terhadap Islam dijadikan alat propaganda. Hal ini misalnya, pasca peristiwa runtuhnya menara kembar WTC di Amerika, terdapat pencarian informasi tentang Islam yang cukup pesat. Hal tersebut dilatarbelakangi karena asumsi mereka terhadap tindakan pelaku pengeboman yang dikaitkan dengan Islam, sehingga memunculkan kesan bahwa Islam sebagai agama teroris. Atas dasar itulah, pencarian informasi berkenaan dengan Islam meningkat sangat signifikan. Dengan hadirnya informasi akurat tentang Islam melalui media internet, akhirnya banyak yang dapat mengubah citra Islam di sana. Melalui informasi media Internet tersebut, sebanyak 34 ribu warga Amerika masuk Islam. ${ }^{37}$ Oleh karenanya, umat Islam perlu secara serius mengisi media virtual tersebut dengan konten-konten yang memiliki nilai-nili edukatif dan Islami. Media internet pada akhirnya, tidak hanya sebagai media untuk mengedukasi masyarakat muslim, namun pada saat bersamaan dapat juga menjadi sarana dakwah bagi mereka non muslim yang mencari kebenaran tentang Islam.

Yusuf Al-Qardhawi dalam penjelasannya terkait jihad dengan lisan dan penjelasan (bayan) untuk masa kini, dapat dilakukan dalam tiga bentuk, yaitu: 1) bayan syafahi, yaitu penjelasan secara lisan sesuai kadar akal masyarakat dalam betuk ceramah, pengajaran, dan perkulihan; 2) bayan tahriri, yaitu penjelasan dalam bentuk tulisan, yang dapat ditulis dengan berbagai bahasa untuk menyampaikan risalah Islam melalui buku-buku, makalah-makalah, bulletin-buletin, riset dan artikel ilmiah yang memberikan penjelasan untuk berbagai level masyarakat; 3) penjelasan melalui dialog (hiwar) yang dapat berupa dialog antar agama atau dialog antar peradaban, yang menunjukan pada jihad melalui argumentasi atau bantahan yang baik. Lebih lanjut AlQardhawi juga menjelaskan bahwa termasuk dalam kategori jihad dengan dialog atau yang mendekatinya adalah penjelasan yang bersifat informatif (bayan I'lami) yang dapat dilakukan melalui kisah, teater, drama, film, dan sinetron bersambung yang disiarkan melalui radio, televisi, sinema, atau panggung teater. ${ }^{38}$

37 Hatta Abdul Malik, "Dakwah Media Internet: Komparasi Situs Islam Di Amerika Dan Indonesia," Jurnal Ilmu Dakwah $36, \quad$ no. 2 (2016): 231 , https://doi.org/https://doi.org/10.21580/jid.v36.2.1749.

38 Al-Qardhawi, Fiqh Al-Jihad: Dirasah Muqaranah Liahkamihi Wa Falsafatihi Fi Doui AlQuran Wa As-Sunnah, 228.

Tribakti: Jurnal Pemikiran Keislaman

Volume 32, Nomor 1, Januari 2021 
Bentuk-bentuk jihad lisan maupun bayan sebagaimana dijelaskan Al-Qardhawi di atas, saat ini dapat dioptimalkan perannya melalui teknologi, seperti pembuatan video-video edukatif, aplikasi pendidikan, buku-buku elektronik dan lain-lain. Pembuatan konten-konten yang akan disajikan dapat disiapkan secara individu oleh ulama, guru, dosen, dan para da'i secara umum atau dengan berkolaborasi dengan berbagai pihak yang menguasai bidang teknologi atau bidang-bidang lainnya. Dengan semakin banyak yang mengisi media digital atau virtual dengan hal-hal yang islami dan edukatif, harapannya akan mampu mengimbangi aspek-aspek negatif dari teknologi informasi. Bila berbagai konten negatif menarik dan mudah diakses, maka konten islami harus lebih menarik dan lebih mudah lagi untuk diakses oleh masyarakat. Upaya untuk mengoptimalkan media virtual dan mengisi dunia maya dengan konten-konten pendidikan dan dakwah tersebut merupakan bagian dari jihad penting di era ini yang perlu diperhatikan secara serius oleh kaum muslimin.

\section{Kesimpulan}

Memasuki era digital, umat Islam dihadapakan pada berbagai masalah umat yang menunjukan tantangan besar bagi umat Islam saat ini, terutama dalam bidang pendidikan. Masalah-masalah tersebut mencakup banyak hal, mulai dari masalah pemikiran, masalah budaya dan gaya hidup, masalah moral, serta masalah kualitas guru dan ketersediaan infrastruktur pendidikan yang belum memadai. Beragamnya masalah tersebut menunjukan urgensitas jihad dalam bidang pendidikan.

Jihad pendidikan menuntut peran kolaboratif semua komponen umat. Peran tersebut dapat dimaknai peran seorang muslim yang bertanggung jawab terhadap kualitas dirinya sendiri dan keluarganya; dan perannya sebagai muslim dalam komunitas masyarakat muslim. Untuk itu umat Islam perlu menempatkan pendidikan sebagai tanggung jawab individu dan sosial. Adapun yang menunjukan bentuk-bentuk aktualisasi jihad dalam bidang pendidikan, di antarannya: 1) jihad melawan hawa nafsu sebagai dasar dalam menjalankan aktivitas jihad lainnya; 2) Jihad bagi orang tua dalam mendidik anak-anaknya; 3) jihad guru dalam mendidik generasi umat; 4) jihad peserta didik dalam menuntut ilmu; 5) jihad harta yang digunkan untuk kepentingan pendidikan Islam; 6) jihad melalui media virtual, yaitu dengan menghadirkan konten-konten edukatif dan Islami di berbagai media digital dalam berbagai bentuk. 


\section{Daftar Pustaka}

Al-Qardhawi, Yusuf. Figh Al-Jihad: Dirasah Muqaranah Liahkamihi Wa Falsafatihi Fi Doui Al-Quran Wa As-Sunnah. 4th ed. Kairo: Dar Al-Kutub Al-Mishriyyah, n.d.

Atem. "Ancaman Cyber Pornography Terhadap Anak-Anak." Jurnal Moral $\begin{array}{lllll}\text { Kemasyarakatan } & 1, & \text { no. } & 2 & \text { (2016): }\end{array}$ https://doi.org/https://doi.org/10.21067/jmk.v1i2.1529.

Badan Pusat Statistik. Potret Pendidikan Indonesia; Statistik Pendidikan Indonesia. Jakarta-Indonesia: Badan Pusat Statistik, 2019.

Chirzin, Muhammad. "Reaktualisasi Jihad Fi Sabil Allah Dalam Konteks Kekinian Dan Keindonesiaan." Ululmuna X, no. 1 (2006): 59-80. https://doi.org/https://doi.org/10.20414/ujis.v10i1.432.

Fatmawati, Nur Ika. "Literasi Digital, Mendidik Anak Di Era Digital Bagi Orang Tua Milenial." Jurnal Politik Dan Sosial Kemasyarakatan 11, no. 2 (2019): 119-38. http://e-jurnal.unisda.ac.id/index.php/MADANI/article/view/1602.

Hamruni. Konsep Edutaiment Dalam Pendidikan Islam. Yogyakarta: Bidang Akademik UIN Sunan Kalijaga, 2008.

Husaini, Adian. Pendidikan Islam (Mewujudkan Generasi Gemilang Menuju Negara Adidaya 2045). Depok: Yayasan Pendidikan At-Taqwa Depok, 2020.

Katsir, Abu Fida bin Isma'il bin. E-Book: Tafsir Ibnu Katsir. Omel kitab.net, n.d.

Lidwa. Ensiklopedia Hadits, Kitab 9 Imam (E-BOOK). Lidwa-Saltanera, n.d.

Majelis Ulama Indonesia. "Pluralisme, Liberalisme, Dan Sekularisme Agama." Himpunan Fatwa MUI, 2005.

Malik, Hatta Abdul. "Dakwah Media Internet: Komparasi Situs Islam Di Amerika Dan Indonesia." Jurnal Ilmu Dakwah 36, no. 2 (2016): 229-42. https://doi.org/https://doi.org/10.21580/jid.v36.2.1749.

Muanawwir, A.W. Kamus Al-Munawwir Arab-Indonesia. Surabaya: Pustaka Progresif, 1997. Su.

Nata, Abuddin. Tafsir Ayat-Ayat Pendidikan. Jakarta: Rajawali Pers, 2014.

Ningrum, Diah. "Kemerosotan Moral Di Kalangan Remaja: Sebuah Penelitian Mengenai Parenting Styles Dan Pengajaran Adab Diah Ningrum Sekolah Menengah Islam Terpadu (SMIT) Al Marjan.” Unisia XXXVII, no. 82 (2015): 1830. https://journal.uii.ac.id/Unisia/article/view/10491/8171.

Novrialdy, Eryzal. "Kecanduan Game Online Pada Remaja: Dampak Dan Pencegahannya." Buletin Psikologi 27, no. 2 (2019): 148-58. https://doi.org/10.22146/buletinpsikologi.47402.

Rahayu Marini Hakim. "Murid Lecehkan Guru Di Instagram, Psikolog: Krisis Moral." Accessed November 23, 2020. https://republika.co.id/berita/qdkigs282/muridlecehkan-guru-di-instagram-psikolog-krisis-moral.

Ramlan, Ramlan, Tengku Erwinsyahbana, and Nurul Hakim. "The Concept of Jihad In Islam.” IOSR Journal of Humanities and Social Science 21, no. 09 (2016): 35-42.

Tribakti: Jurnal Pemikiran Keislaman

Volume 32, Nomor 1, Januari 2021 
https://doi.org/10.9790/0837-2109073542.

Rofiah, Khusniati, and Moh. Munir. "Jihad Harta Dan Kesejahteraan Ekonomi Pada Keluarga Jamaah Tabligh: Perspektif Teori Tindakan Sosial Max Weber." Justicia Islamica: Jurnal Kajian Hukum Dan Sosial 16, no. 1 (2019): 193-218. https://doi.org/10.21154/justicia.v16i1.1640.

Salmah, Sri. "Perilaku Vandalisme Remaja Di Yogyakarta." Media Informasi Penelitian Kesejahteraan Sosial 39, no. 1 (2015): 15-29. https://doi.org/10.31105/mipks.v39i1.534.

Sana, Loue. "AIDS Jihad: Integrating the Islamic Concept of Jihad with HIV Prevention Theory." Journal of Health Care for the Poor and Underserved 22, no. 33 (2011): 720-39. https://doi.org/http://dx.doi.org/10.1353/hpu.2011.0095.

Shihab, M. Quraish. Wawasan Al-Quran. Bandung: PT Mizan Pustaka, 2007.

Simon Kemp. "DIGITAL 2020: INDONESIA," n.d. https://datareportal.com/reports/digital-2020-indonesia.

Suharto, Toto. Filsafat Pendidikan Islam. Yogyakarta: Ar-Ruz, 2006.

Syahidin. "The Teacher Education In Islamic Views: A Conceptual Analysis To Increase Teacher And Lecturer Professionalism Islamic Religious Education In Indonesia." International Journal of Recent Scientific Research 8, no. 10 (2017): 20587-92. https://doi.org/http://dx.doi.org/10.24327/ijrsr.2017.0810.0921.

Ulwan, Abdullah Nasih. Tarbiyyatul Awlad Fil Islam Jilid 1. Beirut: Darusalam, 1992.

Wahyudi, Tian. "Paradigma Pendidikan Anak Dalam Keluarga Di Era Digital (Perspektif Pendidikan Islam)." Ri'ayah 4, no. 01 (2019): 31-43. https://doi.org/https://doi.org/10.32332/riayah.v4i01.1489.

_. "Strategi Pendidikan Akhlak Bagi Generasi Muda Di Era Disrupsi." TA'LIM: Jurnal Studi Pendidikan Islam 3, no. 2 (2020): 14-34. https://doi.org/https://doi.org/10.29062/ta\&\#039;lim.v3i2.

Zed, Mestika. Metode Penelitian Kepustakaan. Jakarta: Yayasan Pustaka Obor Indonesia, 2014. 